\title{
The spatio-temporal distribution of lightning over Israel and the neighboring area and its relation to regional synoptic systems
}

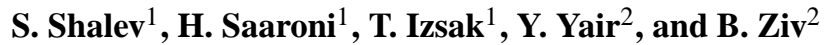 \\ ${ }^{1}$ Dept. of Geography and the Human Environment, Tel-Aviv University, Israel \\ ${ }^{2}$ Dept. of Natural Sciences, The Open University of Israel, Israel
}

Received: 27 March 2011 - Revised: 19 May 2011 - Accepted: 19 May 2011 - Published: 4 August 2011

\begin{abstract}
The spatio-temporal distribution of lightning flashes over Israel and the neighboring area and its relation to the regional synoptic systems has been studied, based on data obtained from the Israel Lightning Location System (ILLS) operated by the Israel Electric Corporation (IEC). The system detects cloud-to-ground lightning discharges in a range of $\sim 500 \mathrm{~km}$ around central Israel $\left(32.5^{\circ} \mathrm{N}, 35^{\circ} \mathrm{E}\right)$. The study period was defined for annual activity from August through July, for 5 seasons in the period 2004-2010.

The spatial distribution of lightning flash density indicates the highest concentration over the Mediterranean Sea, attributed to the contribution of moisture as well as sensible and latent heat fluxes from the sea surface. Other centers of high density appear along the coastal plain, orographic barriers, especially in northern Israel, and downwind from the metropolitan area of Tel Aviv, Israel. The intra-annual distribution shows an absence of lightning during the summer months (JJA) due to the persistent subsidence over the region. The vast majority of lightning activity occurs during 7 months, October to April. Although over $65 \%$ of the rainfall in Israel is obtained during the winter months (DJF), only $35 \%$ of lightning flashes occur in these months. October is the richest month, with $40 \%$ of total annual flashes. This is attributed both to tropical intrusions, i.e., Red Sea Troughs (RST), which are characterized by intense static instability and convection, and to Cyprus Lows (CLs) arriving from the west.
\end{abstract}

Based on daily study of the spatial distribution of lightning, three patterns have been defined; "land", "maritime" and "hybrid". CLs cause high flash density over the Mediterranean Sea, whereas some of the RST days are typified by flashes over land. The pattern defined "hybrid" is a combination of the other 2 patterns. On CL days, only the maritime

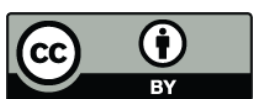

Correspondence to: S. Shalev (sigalit.shalev.1@gmail.com) pattern was noted, whereas in RST days all 3 patterns were found, including the maritime pattern. It is suggested that atmospheric processes associated with RST produce the land pattern. Hence, the occurrence of a maritime pattern in days identified as RST reflects an "apparent RST". The hybrid pattern was associated with an RST located east of Israel. This synoptic type produced the typical flash maximum over the land, but the upper-level trough together with the onshore winds it induced over the eastern coast of the Mediterranean resulted in lightning activity over the sea as well, similar to that of CLs.

It is suggested that the spatial distribution patterns of lightning may better identify the synoptic system responsible, a CL, an "active RST" or an "apparent RST". The electrical activity thus serves as a "fingerprint" for the synoptic situation responsible for its generation.

\section{Introduction}

The eastern Mediterranean Basin is unique in that lightning activity occurs almost exclusively in the winter season, and almost never in the summer (Yair et al., 1998; Altaratz et al., 2003). The conditions for thunderstorm occurrence in the eastern Mediterranean were described by Levin et al. (1996) and are similar to the conditions often found in winter thunderstorms in Japan (Kitagawa and Michimoto, 1994). These storms usually develop within cold and unstable air-masses that move above the relatively warm sea water. For Israel, this air mass is carried inland by the westerly flow associated with Cyprus Lows (CLs, Shay-El and Alpert, 1991). Bands of cumulus clouds, sometimes as shallow as $5 \mathrm{~km}$ (Altaratz et al., 2003; Ganot et al., 2007), approach the coastline and produce intensive rain showers. More active cumulonimbus clouds are sometimes embedded within these clouds.

Cyprus Lows contribute the vast majority of annual rainfall (Goldreich, 2003; Goldreich et al., 2004; Saaroni et al.,

Published by Copernicus Publications on behalf of the European Geosciences Union. 


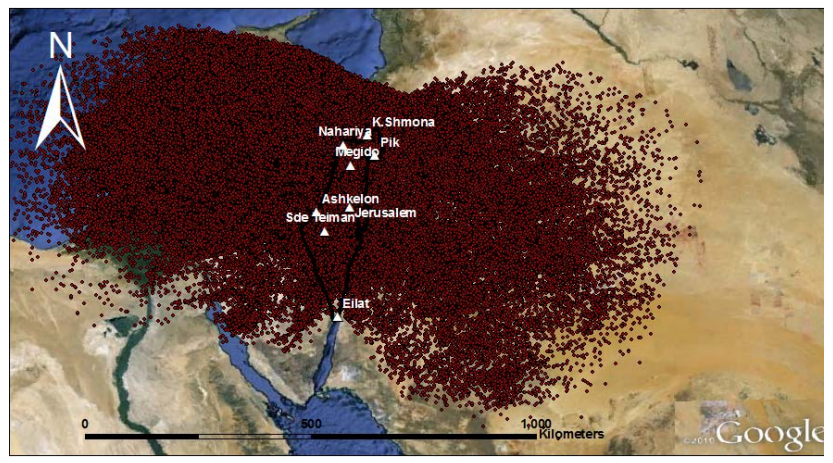

Fig. 1. The study region. Brown dot for each flash detected during the study period. White triangles denote the locations of the ILLS sensors.

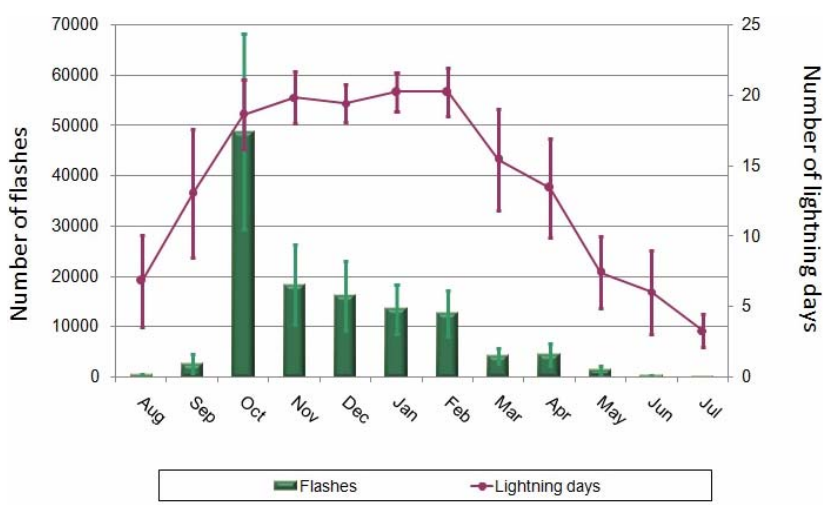

Fig. 2. Average monthly number, and STD (of 1 STD length), for the flashes (bars, left axis) and LDs (graph, right axis) over the study region.

2010a). Red Sea Troughs (RSTs), occurring mostly during autumn, are responsible for severe rain storms and flood events in the eastern and southern parts of Israel (Dayan et al., 2001; Kahana et al., 2002). The RST is a quasi-stationary trough extending from the south, mostly with no significant rainfall (Alpert et al., 2004). When combined with an upper-level trough, it may become an "active RST", characterized by transport of unstable air from tropical sources into the eastern Mediterranean, producing local (heavy) showers, especially over southern and eastern Israel (Saaroni et al., 1998; Kahana et al., 2002). However, most studies on lightning activity over the eastern Mediterranean have focused on the winter season and the CL system (e.g., Altaratz et al., 2003; Price and Federmesser, 2006; Ziv et al., 2009).

The factors that enhance convection, and consequently drive charge separation, electric-field buildup, and eventually, the lightning rate, can be divided into thermodynamic factors, i.e., temperature, moisture content and their vertical profiles, which trigger and support buoyancy-driven ascent, and dynamic factors, which induce convergence and large scale ascending motion. Ziv et al. (2009) studied atmo- spheric factors governing winter thunderstorms in the coastal region of the eastern Mediterranean under CL conditions and showed that winter lightning activity is dominated by thermodynamic factors, mainly the lapse rate throughout the entire cloud layer. The dynamic factors implied by the presence of a CL were found to be secondary, and the lower-level dynamics were found to be insignificant. The differences in the nature of these two synoptic systems, CL and RST, are expressed also in the CAPE, which evaluates the potential for lightning. In RST, Dayan et al. (2001) found values exceeding $1100 \mathrm{~J} \mathrm{~kg}^{-1}$ whereas for CLs Ziv et al. (2009) found much smaller values, in the order of several hundreds of $\mathrm{J} \mathrm{kg}^{-1}$

This study presents an analysis of the spatio-temporal distribution of lightning activity based on cloud-to-ground flashes. The analysis includes inter- and intra-annual distributions and spatial distribution of flash density as a function of the regional synoptic systems.

\section{Data and methods}

The study region is defined by the detection capability of the Israel Lightning Location System (ILLS, Fig. 1) operated by the Israel Electric Corporation (IEC). The operational capabilities are defined such that lightning is detected in a range of $\sim 500 \mathrm{~km}$ from central Israel, but a minimum of three sensors are needed in order to determine the location of a single flash. The distribution of the ILLS sensors in Israel along a north-south axis leads to detection-efficiency minima, which are manifested in a "butterfly" distribution, where flashes at distances greater than $100 \mathrm{~km}$ north or south of this axis are not detected, while in the perpendicular directions (east and west) flashes are sensed up to $500 \mathrm{~km}$ distance.

Evaluations of similar systems around the world gave an overall detection efficiency of $70 \%-90 \%$ for ground flashes. The detection efficiency of the ILLS in Israel is consistent with the specifications over the entire land area of Israel and westward toward the Mediterranean Sea, where most storms arrive from (Altaratz et al., 2003). Over land, where all 8 sensors are located, it is as high as $95 \%$, and it decreases with distance from the network center. The location accuracy of the detected flashes is $0.5-1 \mathrm{~km}$ within the network, and it decreases with distance from central Israel, to $\sim 10 \mathrm{~km}$ near Cyprus. The dimension of the study region in the eastwest direction is therefore about $1000 \mathrm{~km}$ while in the northsouth direction it is only $500 \mathrm{~km}$ (Fig. 1). The area of the study region is $\sim 500000 \mathrm{~km}^{2}$, of which $40 \%$ are over the Mediterranean Sea. The land area of the state of Israel is $\sim 27500 \mathrm{~km}^{2}$, i.e., $5.5 \%$ of the study region.

We used stroke data obtained by the ILLS, including cloud-to-ground both negative and positive. Flashes with a current between 0 and $+10 \mathrm{kA}$ are automatically filtered out, being treated as intra-cloud flashes (Cummins et al., 1998). 


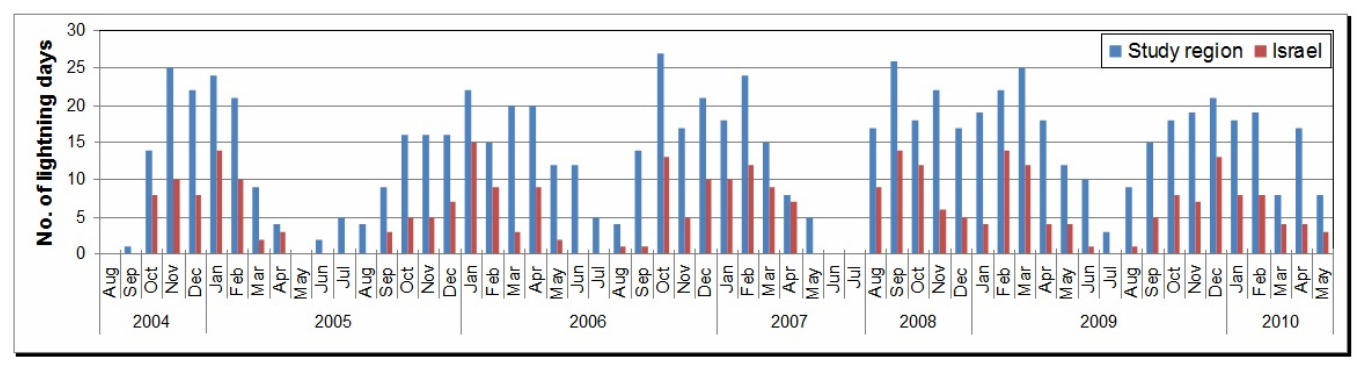

Fig. 3. The number of lightning days over the study region and over Israel for each month of the study period. A lightning day is defined here as a day on which at least one flash was captured.

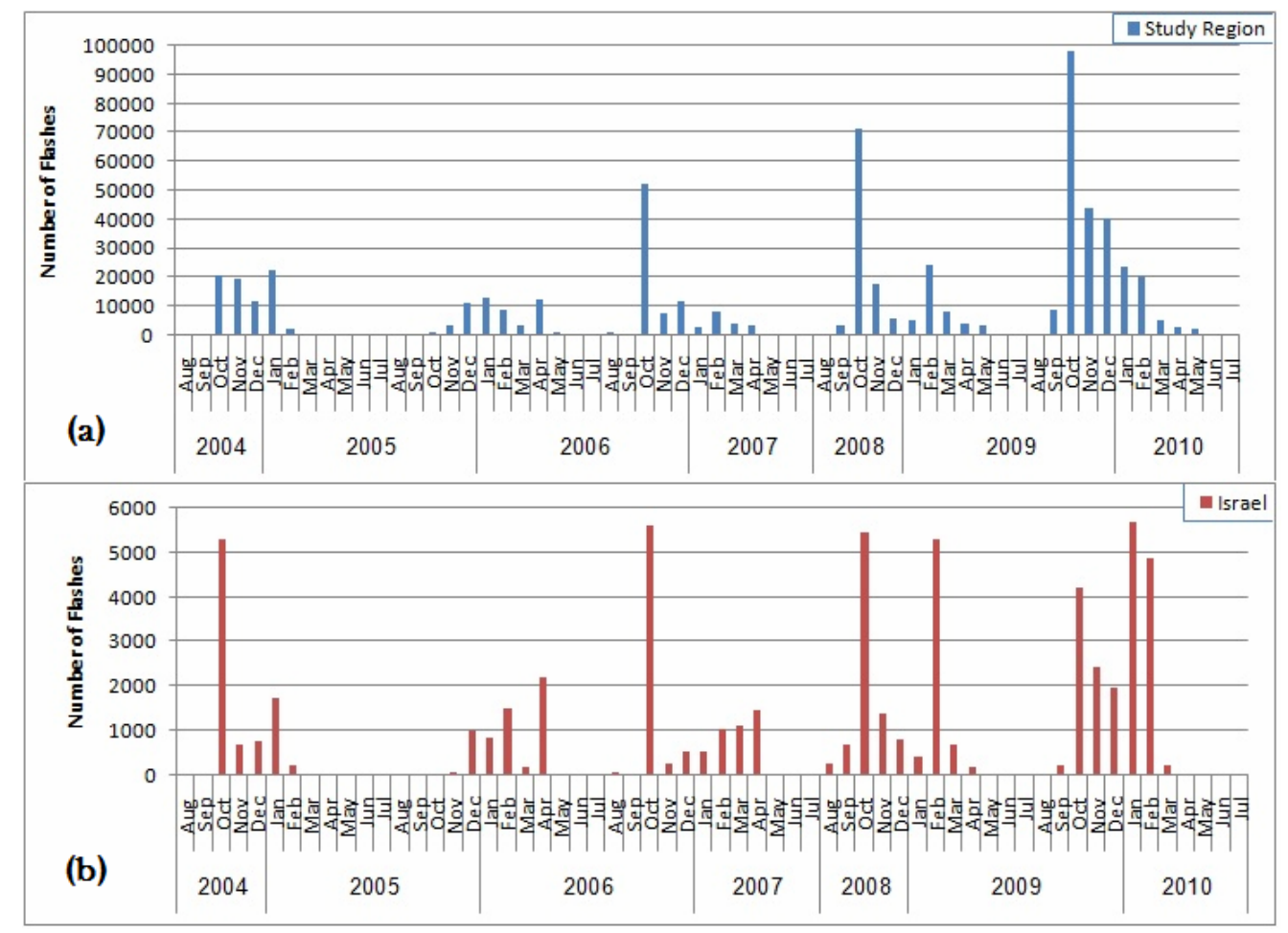

Fig. 4. The number of flashes per month for the study region (a) and for Israel (b).

It should be emphasized that a cloud-to-ground flash can be either a single stroke or have multiple strokes (defined as its multiplicity). The average multiplicity computed for the full stroke data, based on the USA National Lightning Detection Network (NLDN) algorithm and thresholds (10 km and $0.5 \mathrm{~s}$, Rakov and Uman, 2003) is 1.6. We believe that for the ILLS, narrower ranges should be taken with a spatial range of twice the accuracy of the ILLS being $500 \mathrm{~m}$. For the suggested ranges of $1 \mathrm{~km}$ and $0.2 \mathrm{~s}$, the multiplicity computed is 1.1. Therefore, we consider the number of strokes to be representative of the number of flashes.

The lightning data contained for each flash its date, time, location, polarity and peak current. The location coordinates, together with information on the projection used (WGS84), enabled importing the lightning data into ArcGIS format, where a point layer was created. This layer was then processed using other layers such as the map layer. Before importing the data, it was edited and merged into a single layer. ArcGIS enabled slicing and filtering of the data according to the selected properties of each flash (date, time, polarity, intensity and location). Each flash was represented by a point. The spatial distribution maps were derived using the ArcMap version 9.3.1.

A "lightning year" starts on 1 August and ends on 31 July of the consecutive year. This definition is based on the definition of a "rainfall year" (Goldreich, 2003). The study 
Table 1. Number of flashes and number of lightning days (LDs) for each lightning season above the study region and above Israel.

\begin{tabular}{l|rr|rr}
\hline \multirow{2}{*}{ Lightning year } & Study region & & Israel & \\
\cline { 2 - 5 } & No. of flashes & No. of LDs & No. of flashes & No. of LDs \\
\hline $2004 / 2005$ & 76761 & 127 & 8777 & 55 \\
$2005 / 2006$ & 53221 & 167 & 5940 & 58 \\
$2006 / 2007$ & 90131 & 153 & 10701 & 68 \\
$2008 / 2009$ & 140692 & 209 & 15174 & 85 \\
$2009 / 2010$ & 244608 & 161 & 19703 & 62 \\
\hline Sum & $\mathbf{6 0 5 4 1 3}$ & $\mathbf{8 1 7}$ & $\mathbf{6 0 2 9 5}$ & $\mathbf{3 2 8}$ \\
\hline Average & $\mathbf{1 2 1 0 8 3}$ & $\mathbf{1 6 3}$ & $\mathbf{1 2 0 5 9}$ & $\mathbf{6 6}$ \\
\hline Standard deviation & 76110 & 30 & 5436 & 12 \\
\hline
\end{tabular}

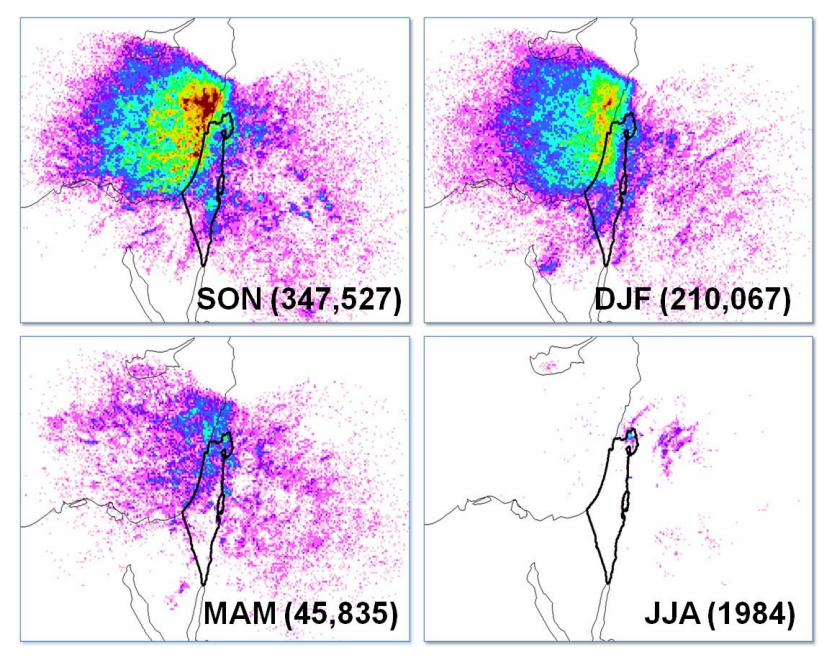

Fig. 5. Spatial distribution of flash density for each season in terms of the number of flashes $/ 25 \mathrm{~km}^{2}$ per year, using a cell size of $5 \mathrm{~km}^{2}$. The decrease in the number of flashes to the far west and east is associated with the system's inability to monitor flashes that occur at a great distance.

period includes 5 yr: 2004/2005, 2005/2006, 2006/2007, 2008/2009, 2009/2010.

For each lightning day (LD), a day on which at least one flash was detected by the ILLS in the study region, the synoptic system that prevailed over the study region was determined and listed, according to the semi-objective classification of Alpert et al. (2004). This classification contains five main systems: RST, CLs, Persian Trough, Highs and North African (Sharav) Lows, and is based on the 12:00 UTC 1000-hPa temperature and horizontal wind and GPH, taken from the NCEP-NCAR dataset, with a $2.5^{\circ} \times 2.5^{\circ}$ resolution (Kalnay et al., 1996; Kistler et al., 2001). According to Alpert et al. (2004), the regional weather phenomena are well defined by these synoptic systems and the upper-level systems are clearly reflected when one considers the dynamics of the east Mediterranean surface synoptic systems. The synoptic maps presented here were derived using the NCEP/NCAR reanalysis data.

\section{Results}

\subsection{Inter-annual and intra-annual distributions}

During this study the ILLS detected 605413 cloud-to-ground (CG) lightning flashes over the entire study region, collected during 817 lightning days (LDs), i.e. $45 \%$ of the days of the study period. When excluding LDs with fewer than 5 flashes ( $40 \%$ of the LDs), the average number of LDs for the study region is $98 \pm 17$ per year. For a threshold of 100 flashes per day, the average number of days is $57 \pm 5$, i.e. $35 \%$ of the LDs.

The ratio of detected lightning over Israel and over the entire region is 1:10 (Table 1), about twice the aerial ratio. This is clearly the result of the better detection efficiency of the ILLS system because its location lies in Israel. Moreover, the respective ratio for the number of LDs is considerably larger, 2:5. These differences are further discussed with regard to the lightning spatial distribution.

The isoceraunic map for Israel (prepared by the Israel Meteorological Service, Nautra, 1982) indicates a much lower number of LDs, ranging between 2 in the South of Israel to 30 in the North. The large difference in these results is attributed to the different methodology applied and mainly to the change in the detection method from the old, traditional, human-based acoustic hearing of thunder by the local weather observer (limited to approximately $20 \mathrm{~km}$ ), to the far more accurate and long-range monitoring based on electromagnetic radiation from lightning by the ILLS.

Table 1 indicates the large inter-annual variations, as for example between 53221 flashes in 2005/2006 (over the entire study region) and 244608 flashes in 2009/2010. This 
reflects the high variability in the occurrence of the relevant synoptic systems (Saaroni et al., 2010a, b and see Sect. 3.3).

The intra-annual distribution of lightning activity over the region indicates that it occurs during the autumn, winter and spring but hardly during the summer months (JJA, see Figs. 2-4). The absence of lightning during the summer months is attributed to the persistent higher-level subsidence over the region (Rodwell and Hoskins, 1996; Ziv et al., 2004). However, rain episodes are observed over the northern half of Israel almost every year, and found to be rather mild and highly localized (Saaroni and Ziv, 2000). They suggested that the cause of rain is not a synoptic-scale forcing, but rather a weakening of the rain-suppressive thermodynamic conditions over the Levant region. The main lightning season is October-February, in which $90 \%$ of the total flashes are recorded (Fig. 2). The average number of flashes in both October and November is larger than that of each of the winter months, DJF. Moreover, October is the richest month with flashes, about 3 times more than the average for the months November-February (Fig. 2).

As for LDs, the period October-February is also shown as the high season, with a flat distribution ranging from 18.6 to $20.2 \mathrm{LDs}$ per month (Fig. 2). However, their percentage is only $60 \%$ of the yearly amount. The ratio between the monthly number of flashes and the number of LDs for a certain month is the average number of flashes per a LD in the pertinent month. Figure 2 implies that the average number of flashes per lightning day for October, being 2617, is the largest and is almost 4 times larger than that for NovemberFebruary.

The inter-annual variations, as represented by the relative STDs inferred from Fig. 2, are more or less similar for the number of flashes $(\sim 20 \%)$ for the months OctoberFebruary. However, for the number of LDs, October has the largest STD, about 1.5-2 times that of DJF. Figures 3 and 4 present the number of LDs and flashes, respectively, for each individual month of the study period over the entire study region (in blue) and over Israel (in red), reflecting the large inter-annual variability. October flashes account for $40 \%$ of the detected flashes in the study region and $34 \%$ in Israel. Flashes in DJF months account for an average of $35 \%$ of the total flashes detected in the study region and $45 \%$ above Israel. This suggests that low correlation exists between the number of flashes and the number of lightning days. The correlation (on a monthly basis) was calculated for the months October-February, yielding correlation of $R=0.13$ and for DJF - 0.26, both insignificant. As an example, in October 2009 an extremely high number of flashes, 98000 , was measured within 18 lightning days, whereas in October 2005, only 929 flashes $(\sim 1 \%)$ were observed within almost the same number (16) of lightning days. This means that the number of flashes at a given storm is highly dependant on the specific atmospheric conditions, which determine the efficiency of charge separation and lightning generation.

\subsection{Spatial distribution of lightning flash density}

The spatial distribution of flash density for each of the four seasons is presented in Fig. 5. Several features can be observed. The most prominent one is the absence of flashes during the summer (JJA), except for local centers of low density over the mountain areas in the northern part of the study region. This fact can be partly explained by exceptional events of deep Persian Trough causing summer rainfall (Saaroni and Ziv, 2000). The dominant feature appearing in the autumn (SON), winter (DJF) and spring (MAM), is the higher lightning density over the Mediterranean Sea than over the land, reflecting the major contribution of the CLs to the lightning flash density, as widely studied by Levin et al. (1996), Yair et al. (1998), Altaratz et al. (2003) and Ziv et al. (2009). Moreover, the highest density is at the eastern part of the sea, near the coastline. This can be attributed to the contribution of sensible and latent heat fluxes to the air masses while moving over the sea toward the eastern coast (Shay El and Alpert, 1991; Alpert et al., 1990; Ziv et al., 2009; Saaroni et al., 2010a). Similar results were found for the west coast of Japan in the winter season, most notably in the Hokuriku region (Kitagawa and Michimoto, 1994). The decrease in flash density in the spring is attributed to the relatively cool SST in that season and the northward shift of the cyclone's track toward Europe (Alpert et al., 1990). The highest flash density in the autumn, mostly in October (see Sect. 3.1), may be attributed to the highest SST in that month for the entire lightning season.

The decrease in lightning density from north to south can be explained by the growing distance from the cyclone's track (Alpert et al., 1990) in that direction. A high flash density is observed parallel to the coast compared to further inland, suggesting that the friction effect of the coastline is being "felt" by the westerly flow, leading to convergence and enhanced convection. The observed decrease to the east of the mountain ridges is caused by the rain-shadow effect downwind from the north-south mountain ridge. Besides the dense centers over the sea, other centers of high density are seen over the eastern and southern parts of the study region. This implies an effect of other synoptic systems such as the RST (Dayan et al., 2001; Kahana et al., 2002) and tropical plumes (Ziv, 2001), as is exemplified and discussed in Sect. 3.3.

Figure 6 shows the flash density over Israel. Regional maxima can be noted along the coastal plain, orographic barriers, especially in northern Israel, and downwind from the metropolitan area of Tel Aviv. The increase at the coastline expresses the friction effect of the coast known also to increase the rate of convective rains over the coastal plain of Israel (Sharon and Kutiel, 1986). The maximum over the mountains is due to the orographic forcing and is consistent with the increase in the orographic rains (Sharon and $\mathrm{Ku}$ tiel, 1986; Goldreich, 2003). The high flash density downwind from the metropolitan area of Tel Aviv (especially to 
Table 2. Instability indices for the 3 case studies, including the day prior to and after their occurrence.

\begin{tabular}{|c|c|c|c|c|c|}
\hline & \multicolumn{2}{|c|}{ Daily number of Strokes } & \multirow{2}{*}{$\begin{array}{l}\text { Lifted } \\
\text { index }\end{array}$} & \multirow{2}{*}{$\begin{array}{r}\text { Convective Available } \\
\text { Potential Energy CAPE }\end{array}$} & \multirow{2}{*}{$\begin{array}{l}\text { CAPE using } \\
\text { virtual temp. }\end{array}$} \\
\hline & $\begin{array}{r}\text { Over the entire } \\
\text { study region }\end{array}$ & $\begin{array}{l}\text { Over } \\
\text { Israel }\end{array}$ & & & \\
\hline \multicolumn{6}{|c|}{ "Active RST" 29 October 2004 (Fig. 7) } \\
\hline $\begin{array}{l}00 Z 28 \text { Oct } 2004 \\
12 Z 28 \text { Oct } 2004\end{array}$ & 3297 & 1298 & $\begin{array}{l}-9.79 \\
-9.33\end{array}$ & $\begin{array}{l}3220.83 \\
3309.98\end{array}$ & $\begin{array}{l}3430.95 \\
3464.93\end{array}$ \\
\hline $\begin{array}{l}00 Z 29 \text { Oct } 2004 \\
12 Z 29 \text { Oct } 2004\end{array}$ & 13939 & 3890 & $\begin{array}{r}-10.47 \\
-4.57\end{array}$ & $\begin{array}{l}3655.80 \\
1145.85\end{array}$ & $\begin{array}{l}3856.45 \\
1259.37\end{array}$ \\
\hline $\begin{array}{l}\text { 00Z } 30 \text { Oct } 2004 \\
12 Z 30 \text { Oct } 2004\end{array}$ & 1129 & 9 & $\begin{array}{l}-3.53 \\
-9.79\end{array}$ & $\begin{array}{l}1060.56 \\
3220.83\end{array}$ & $\begin{array}{l}1215.11 \\
3430.95\end{array}$ \\
\hline \multicolumn{6}{|c|}{ "Maritime" type, 30 October 2009 (Fig. 8) } \\
\hline $\begin{array}{l}\text { 00Z } 29 \text { Oct } 2009 \\
12 Z 29 \text { Oct } 2009\end{array}$ & 31180 & 932 & $\begin{array}{r}0.83 \\
-1.01\end{array}$ & $\begin{array}{r}24.52 \\
313.32\end{array}$ & $\begin{array}{r}38.25 \\
377.84\end{array}$ \\
\hline $\begin{array}{l}00 Z 30 \text { Oct } 2009 \\
12 Z 30 \text { Oct } 2009\end{array}$ & 27933 & 2451 & $\begin{array}{l}-2.43 \\
-0.32\end{array}$ & $\begin{array}{l}705.92 \\
102.92\end{array}$ & $\begin{array}{l}771.27 \\
123.44\end{array}$ \\
\hline 00Z 31 Oct 2009 & 25772 & 691 & -2.30 & 484.72 & 545.01 \\
\hline \multicolumn{6}{|c|}{ "Hybrid" type, 24 October 2008 (Fig. 9) } \\
\hline $\begin{array}{l}\text { 00Z } 23 \text { Oct } 2008 \\
12 Z 23 \text { Oct } 2008\end{array}$ & 7550 & 218 & $\begin{array}{l}-4.09 \\
-2.35\end{array}$ & $\begin{array}{r}1279.30 \\
684.06\end{array}$ & $\begin{array}{r}1415.34 \\
799.48\end{array}$ \\
\hline $\begin{array}{l}00 Z 24 \text { Oct } 2008 \\
12 Z 24 \text { Oct } 2008\end{array}$ & 19840 & 1709 & $\begin{array}{l}-5.39 \\
-2.23\end{array}$ & $\begin{array}{r}1130.35 \\
482.64\end{array}$ & $\begin{array}{r}1260.25 \\
569.70\end{array}$ \\
\hline $\begin{array}{l}00 Z 25 \text { Oct } 2008 \\
12 Z 25 \text { Oct } 2008\end{array}$ & 1918 & 427 & $\begin{array}{l}-5.00 \\
-1.91\end{array}$ & $\begin{array}{r}1422.61 \\
381.34\end{array}$ & $\begin{array}{r}1555.28 \\
457.13\end{array}$ \\
\hline
\end{tabular}

the northeast, in line with the south-westerly flow during rain events) might reflect the urban heat island effect (Oke, 1987) that has been documented in Tel Aviv (Saaroni et al., 2000).

\subsection{Temporal and spatial distributions in relation to the regional synoptic systems}

The Cyprus Low is the synoptic system contributing the vast majority, $>80 \%$, of the rainfall in Israel (Saaroni et al., 2010a). Other rain-producing systems, particularly of a tropical source, such as the "active RST" (e.g. Dayan et al., 2001) or tropical plume (e.g. Rubin et. al., 2007) have only a minor contribution to the rainfall in Israel. Saaroni et al. (2010a) found that the daily average rainfall observed on rainy days when no CL was present was one order of magnitude smaller $\left(<2 \mathrm{~mm} \mathrm{day}^{-1}\right)$ than on CL days.

The synoptic classification used shows that $>85 \%$ of the flashes occurred on days defined as CL or RST, indicating the dominance of these two systems for lightning activity in the region. In contrast to the small portion of rainfall imparted by RST (i.e., $<20 \%$, Saaroni et al., 2010a) $32 \%$ of the flashes occurred on RST days. However, the relative contribution of the two dominating systems varies along the lightning season. During the winter (DJF) $71 \%$ of the flashes are associated with CLs, still considerably lower than the relative rainfall yield associated with this system, and $19 \%$ with RST. During the autumn (SON) the ratio is reversed; $41 \%$ of the flashes are associated with CLs and $43 \%$ - with RST.

Cyprus Lows have been mentioned as the cause for the maximum lightning density over the sea. In contrast, the "active Red Sea Troughs" usually produce local showers associated with lightning activity, especially over southern and eastern Israel (Kahana et al., 2002). Therefore, one can expect that the RST would produce different spatial distributions of lightning, with its maximum over land.

When analyzed on a daily basis, we identified three different types of lightning distributions and defined these as "land", "maritime" and "hybrid" types. They are exemplified by three case studies specified below and shown in Figs. 7b, 8 b and 9b. For each case the instability of the atmosphere was quantified by the lifted index and the convective 


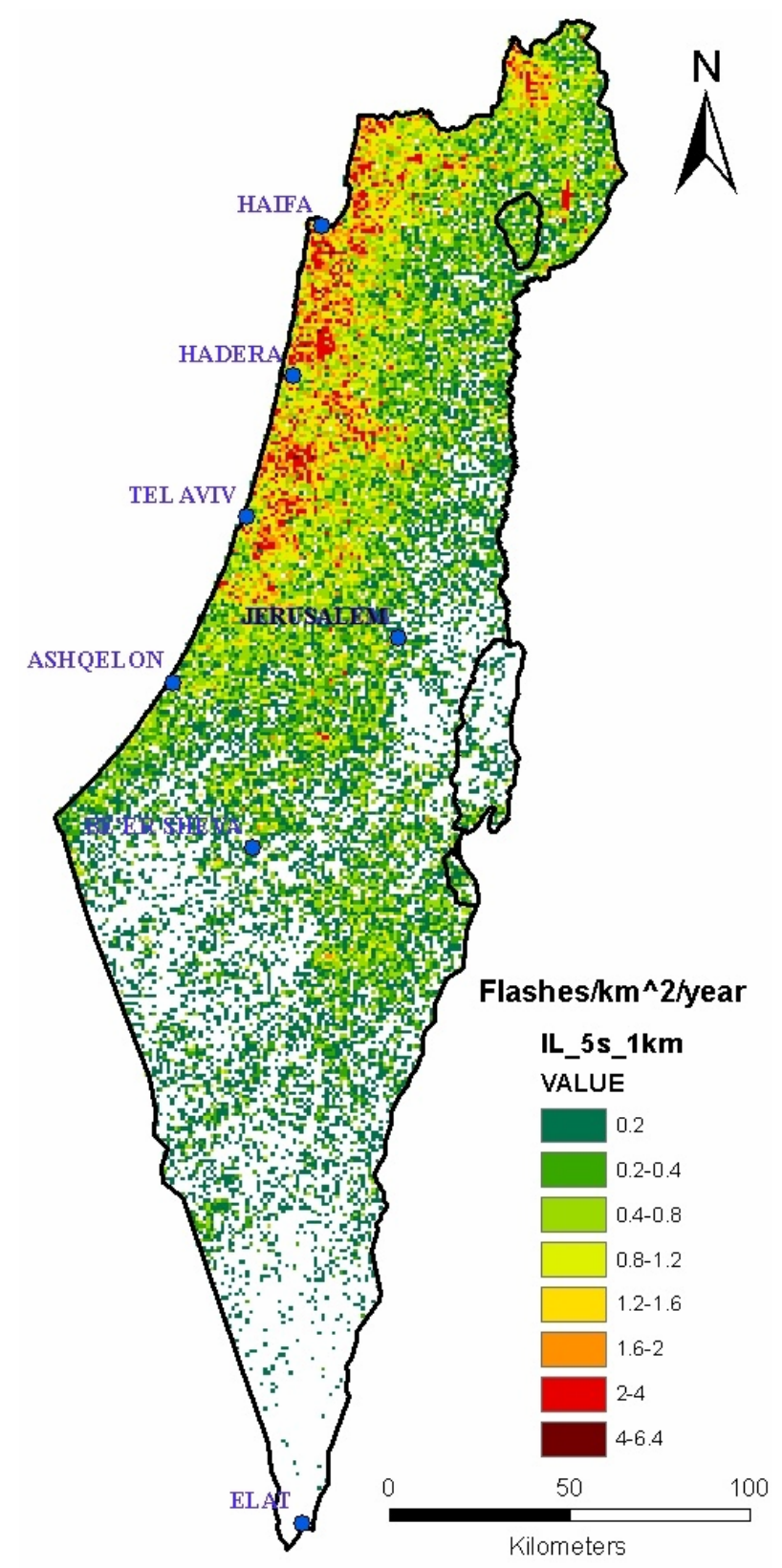

Fig. 6. Spatial distribution of flash density per $1 \mathrm{~km}^{2} \mathrm{yr}^{-1}$ over Israel, based on cell size of $1 \mathrm{~km}^{2}$.

available potential energy (CAPE), based on temperature and on virtual temperature (Table 2 ).

\subsubsection{The "land" type}

The "land" type, exemplified by 29 October 2004 (Fig. 7), was defined synoptically as an RST day. The sea-level pressure (SLP) map (Fig. 7a) shows an RST extending from the south. In the upper-levels (not shown), a trough was located over the eastern Mediterranean, extending toward Egypt with southwesterly to southerly winds, accompanied by transport of moisture from tropical origin. The pronounced instability that developed over the study region can be deduced from the extremely high CAPE seen in Table 2, much higher than is common for lightning events in Israel (Dayan et al., 2001; Ziv et al., 2009). Consequently, cumulonimbus clouds developed over the eastern part of the study region, mostly over the land area and the northeastern part of the Mediterranean, as can be seen in the MODIS satellite image taken at 11:00 UTC (Fig. 7c) and in the daily distribution of the flashes (Fig. 7b). The total number of flashes over the entire study region was $13939,28 \%$ of them over Israel (Table 2).

\subsubsection{The "maritime" type}

The "maritime" type, exemplified by 30 October 2009 (Fig. 8), was defined synoptically as a CL whose center was located east of Cyprus. The SLP map (Fig. 8a) shows the low and the westerly to southwesterly flow transporting moisture from the Mediterranean towards its eastern part. The lightning distribution (Fig. 8b) is most similar to the flash density map of the winter type (Fig. 5), that is mostly over the sea, the adjacent coastal plain and the northern mountains of Israel. The total flash number in that event was 27933 , the vast majority of which was over the Mediterranean Sea and only $9 \%$ over Israel (Table 2 ). A massive cluster of cumulonimbus clouds over this area is clearly seen in the MODIS satellite image taken at 08:20 UTC (Fig. 8c). In this case study the values of both the CAPE and the lifted index were only $1 / 5$ of the respective values for the "land" type and the number of flashes over Israel was $2 / 3$ of those in the "land" type.

\subsubsection{The "hybrid" type}

The "hybrid" type, exemplified by 24 October 2008 (Fig. 9), was defined synoptically as an RST. The lightning distribution (Fig. 9b) is composed of two distinct centers, one over the Mediterranean Sea, most similar to the 'maritime' type (i.e., a CL type), and the second over south eastern Israel, resembling the characteristics of the "land" type (i.e., RST type). The SLP map (Fig. 9a) shows an RST, located east of Israel, with a cyclonic extension toward Cyprus and the northeastern corner of the Mediterranean. The pressure gradient leading to marine northwesterly onshore winds together with a pronounced upper-level trough (not shown) resulted in high instability that supported the development of thunderclouds, most similar to those induced by a CL. This trough moved eastward and crossed Israel during the evening, and the lightning activity propagated accordingly from the sea to the land. The satellite image from 11:05 UTC (Fig. 9c) shows only the clouds over the sea, since the clouds and flashes developed over the land during the late afternoon hours, when no MODIS image was available. The apparent contradiction between the synoptic system defined semi-objectively as RST that implies "land" type lightning 

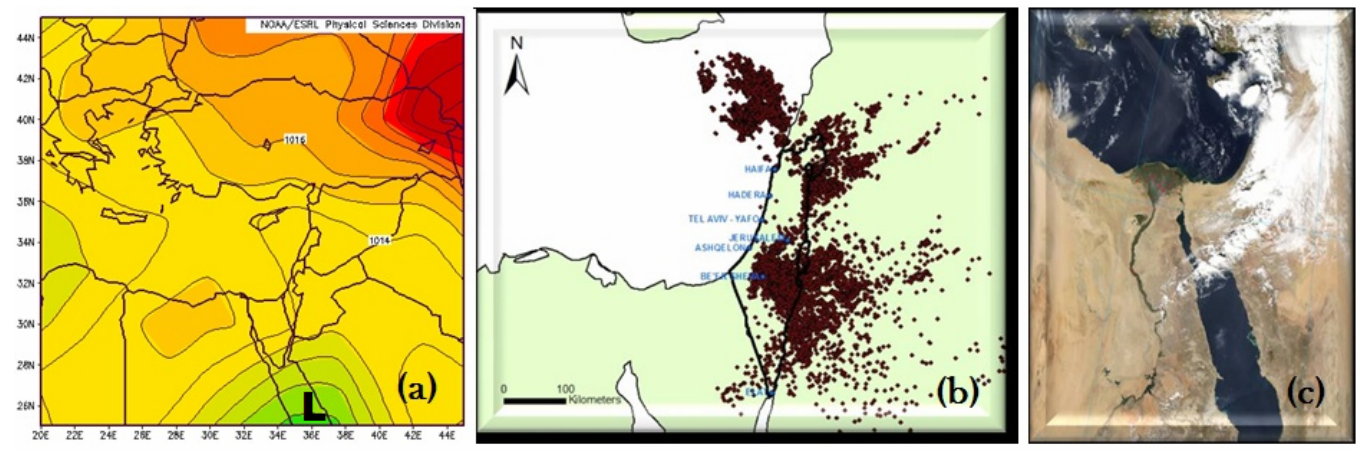

Fig. 7. The daily SLP map (hPa, a), the daily distribution of the lightning flashes (b) and the MODIS satellite image (http://www.nasa.gov/ about/highlights/HP_Privacy.html\#links) taken at 11:00 UTC, for the "land" type, 29 October 2004.
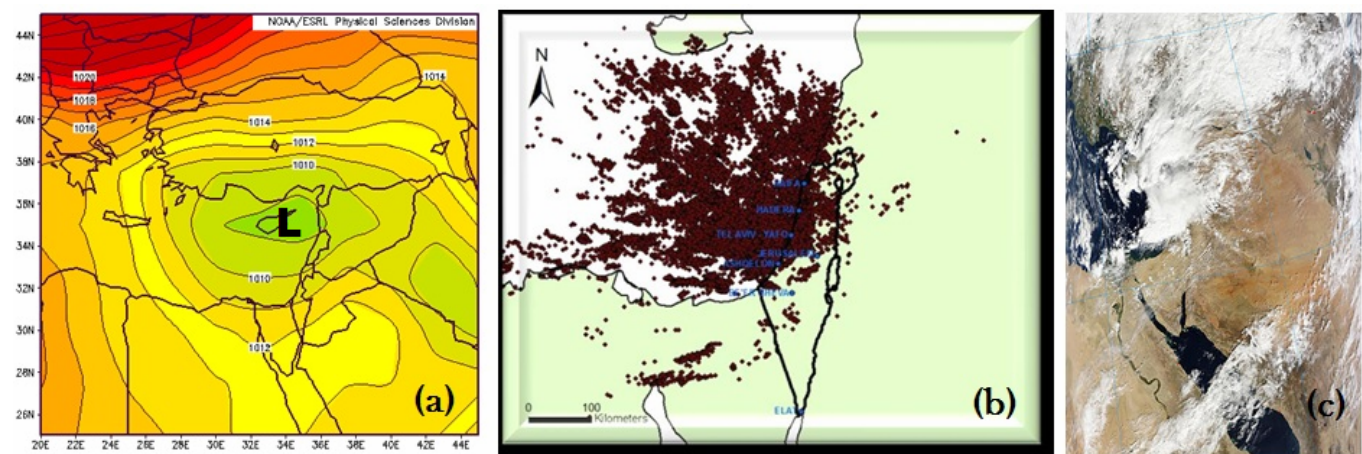

Fig. 8. As in Fig. 7 but for the "maritime" type, 30 October 2009. The MODIS satellite image was taken at 08:20 UTC.
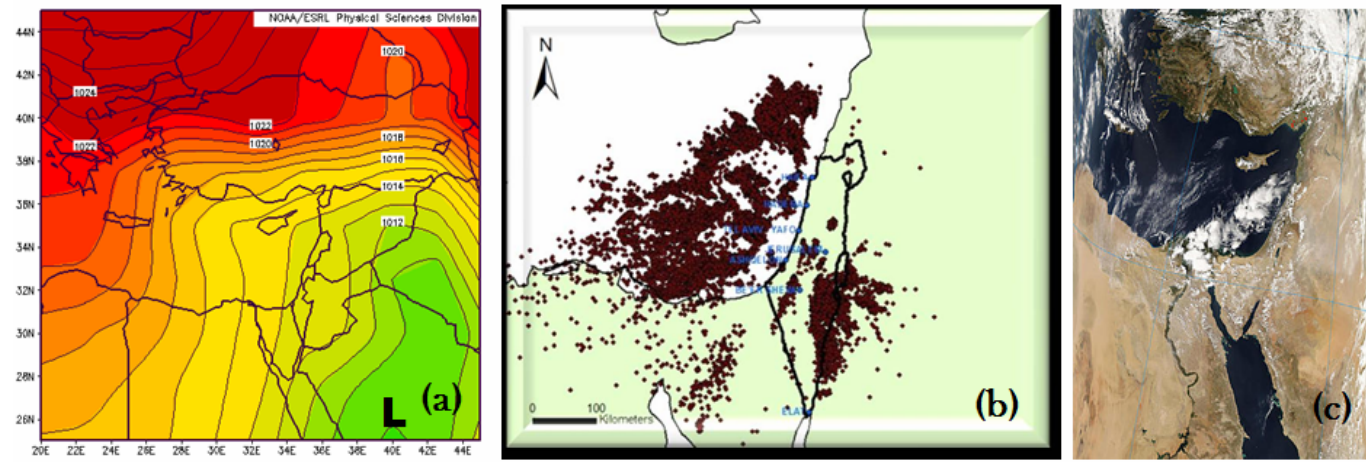

Fig. 9. As in Fig. 7 but for the "hybrid" type, 24 October 2008. The MODIS satellite image was taken at 11:05 UTC. 
distribution, and the pronounced (and even dominant) maximum over the sea can be explained by the specific position of the RST. The axis of the surface trough was located $\sim 7^{\circ}$ east of the coastline, so that Israel was subjected to a marine northwesterly flow, most similar to that induced by a "classical" Cyprus Low. At the same time, the inner land areas were still under the influence of the RST.

A more pronounced apparent contradiction was observed between the synoptic system defined for certain days and the lightning distribution, i.e., days defined as RST with a "maritime" type lightning distribution. It is suggested that these days express Cyprus Lows that develop within an RST (as described in Romem et al., 2007) and therefore, we propose the definition of an "apparent RST" for such situations.

\section{Discussion and conclusions}

Lightning activity in Israel and the neighboring area occurs almost exclusively in the winter months DJF (Yair et al., 1998; Altaratz et al., 2003). Thus, most studies on lightning activity over the region focus on the winter season and the major synoptic system responsible for lightning, namely the Cyprus Low (e.g., Ziv et al., 2009). Another type of weather system that brings heavy rain (which in some cases causes flash floods in the eastern and southern parts of Israel), and is associated with severe thunderstorms, is the "active RST" (e.g., Dayan et al., 2001; Kahana et al., 2002). The atmospheric factor that activates the RST is an upperlevel trough extending from the eastern Mediterranean toward Egypt (Saaroni et al., 2010b). This system is most frequent in the autumn, but may occur also during the winter and spring (Kahana et al., 2002).

This study analyzes the spatio-temporal distribution of lightning flashes over the region and its relation to the regional synoptic systems. The study is based on the annual lightning data obtained from the Israel Lightning Location System (ILLS) operated by the Israel Electric Company (IEC) for a $5 \mathrm{yr}$ period, from 2004 through 2010.

In spite of the fact that over $65 \%$ of the rainfall in Israel is obtained in the winter months, DJF (Goldreich, 2003; Saaroni et al., 2010a), only $35 \%$ of the lightning flashes and $45 \%$ of the lightning days occurred during these three months. Price and Federmesser (2006), in a study based on analysis of lightning data in individual winter storms in the central and eastern Mediterranean from the lightning imaging sensor (LIS) on board the TRMM satellite, found a high positive correlation between lightning activity and rainfall. These correlations can be considered as instantaneous since the LIS offers a snapshot view of the storm. Our results, however, indicate that this correlation does not hold on an annual basis.

October was found to be the richest month in lightning activity, with $40 \%$ of the total flashes, but only $14 \%$ of the lightning days. This indicates a high flash density in Oc- tober with the highest peaks of flashes per day. Eight out of the ten days with $>10000$ flashes occurred in October, reaching a maximum of 31179 flashes at 29 October 2009. This reflects the intense static instability often found in that month, attributed to the lower level warm air accompanied by upper-level cold air due to an upper-level trough (e.g., Dayan et al., 2001). The lower level warm air results from the relatively warm Mediterranean Sea in the autumn $\left(>25^{\circ} \mathrm{C}\right.$, NCEP/NCAR reanalysis) or lower-level warm tropical air transport from south. Moreover, in the fall the tropopause is higher compared to winter, and thus enables the development of convective clouds with a larger vertical dimension. Price and Rind (1992) showed that the total lightning activity is proportional to the 5th power of the vertical cloud dimension, which goes in line with our results.

Two different synoptic systems were found to dominate lightning activity over the study region: the Cyprus low (which accounts to $54 \%$ of the flashes) and the active Red Sea Trough $(32 \%)$. It was also found that over $80 \%$ of the days defined as CLs were associated with lightning, a manifestation of the high static instability associated with these cyclones. As for the RST days, only $60 \%$ of them were associated with lightning. The RST that existed in the days without lightning can be called "inactive RST", a result of the absence of an upper-level trough that is needed to support convection and the development of thunderstorms. It should be noted that both synoptic systems are different from those supporting lightning activity in the central Mediterranean. For example, Mazarakis et al. (2008) studied lightning activity in Greece and the Ionian Sea during the warm season (May-September), a period in which there are practically no thunderstorms in our study area. They found that active days are typified by high values of CAPE and instability at the lower levels, supported by the presence of an upper level trough along the northern Ionian Sea. Additionally, topography plays a dominant factor and most lightning occurs over land, with minima above the sea.

The spatial distribution of lightning flashes on a daily basis enabled the identification of three distribution patterns, defined as "land", "maritime" and "hybrid". While the "land" and "maritime" types are characterized by maxima in flash density over the land and sea, respectively, the "hybrid" type has maxima over both areas. These patterns are expected to express the synoptic factor, i.e., the "maritime" type is strongly related to the CLs and the 'land' type to the "active RST". However, some of the days with "maritime" type were defined by the semi-objective classification (Alpert et al., 2004) as RST rather than Cyprus Low. Therefore, it is suggested to define the synoptic type of such days as "apparent RST", contrary to the "active RST" that has a typical "land" pattern distribution of flash density.

The case study that exemplified the "hybrid" type was identified synoptically as an RST. Besides the maximum of lightning density over the land, a high flash density was also found over the sea, resembling, at least partly, the "maritime" 
type which is typical of a Cyprus Low. The lighting cluster over the sea is explained by the location of the RST to the east of Israel, causing a marine northwesterly flow toward the eastern coast of the Mediterranean, which is conducive to the generation of convective clouds. Together with the pronounced upper-level trough, the resulting atmospheric conditions are similar to those induced by a CL, leading to intense lightning activity.

To conclude, it is suggested that the spatial distribution patterns of lightning help to better distinguish between the synoptic system responsible, a CL, an "active RST" or an "apparent RST". The electrical activity thus serves as a "fingerprint" for the synoptic conditions responsible for its generation.

Acknowledgements. This study was supported by the Israeli Science Foundation (ISF, grant No. 108/10). The authors thank the Israeli Electrical Company (IEC) for providing the lightning data.

Edited by: K. Lagouvardos

Reviewed by: two anonymous referees

\section{References}

Alpert, P., Neeman, B. U., and Shay-El, Y.: Climatological analysis of Mediterranean cyclones using ECMWF data, Tellus, 42A, 6577, 1990.

Alpert, P., Osetinsky, I., Ziv, B., and Shafir, H.: Semi-objective classification for daily synoptic systems, application to the Eastern Mediterranean climate change, Int. J. Climatol., 24, 1001-1011, 2004.

Altaratz, O., Levin, Z., Yair, Y., and Ziv, B.: Lightning activity over land and sea on the eastern coast of the Mediterranean, Mon. Weather. Rev., 131, 2060-2070, 2003.

Cummins, K. L., Murphy, M. J., Bardo, E. A., Hiscox, W. L., Pyle, R. B., and Pifer, A. E.: A combined TOA/MDF technology upgrade of the U.S. National Lighting Detection Network, J. Geophys. Res., 103(D8), 9035-9044, 1998.

Dayan, U., Ziv, B., Margalit, A., Morin, E., and Sharon, D.: A severe autumn storm over the Middle-East: Synoptic and mesoscale convection analysis, Theor. Appl. Climatol., 69, 103122, 2001.

Ganot, M., Yair, Y., Price, C., Ziv, B., Sherez, Y., Greenberg, E., Devir, A., and Yaniv, R.: First detection of transient luminous events associated with winter thunderstorms in the eastern Mediterranean, Geophys. Res. Lett., 34, L12801, doi:10.1029/2007GL029258, 2007.

Goldreich, Y.: The Climate of Israel: Observation, Research and Application, Kluwer Academic Publishes, New York, 2003.

Goldreich, Y., Moses, H., and Rosenfeld, D.: Radar analysis of cloud systems and their rainfall yield in Israel, Isr. J. Earth Sci., 53, 63-76, 2004.

Kahana, R., Ziv, B., Enzel, Y., and Dayan, U.: Synoptic climatology of major floods In the Negev desert, Israel, Int. J. Climatol., 22, 867-822, 2002.

Kalnay, E., Kanamitsu, M., Kistler, R., Collins, W., Deaven, D., Gandin, L., Iredell, M., Saha, S., White, G., Woollen, J., Zhu, Y., Chelliah, M., Ebisuzaki, W., Higgins, W., Janowiak, J., Mo,
K. C., Ropelewski, C., Wang, J., Leetmaa, A., Reynolds, R., Jenne, R., and Joseph, D.: The NCEP/NCAR 40-Year Reanalysis Project, Bull. Ame. Meteor. Soc., 77, 437-471, 1996.

Kistler, R., Kalnay, E., Collins, W., Saha, S., White, G., Woollen, J., Chelliah, M., Ebisuzaki, W., Kanamitsu, M., Kousky, V., Van Den Dool, H., Jenne, R., and Fiorino, M.: The NCEP-NCAR 50year reanalysis: Monthly means CD-ROM and documentation, Bull. Ame. Meteor. Soc., 82, 247-267, 2001.

Kitigawa, N. and Michimoto, K.: Meteorological and electrical aspects of winter thunderclouds, J. Geophys. Res., 99, 1071310721, 1994.

Levin, Z., Yair, Y., and Ziv, B.: Positive cloud-to-ground flashes and wind shear in Tel-Aviv thunderstorms, Geophys. Res. Lett., 23, 2231-2234, 1996.

Mazarakis, N., Kotroni, V., Lagouvardos, K., and Argiriou, A. A.: Storms and lightning activity in Greece during the warm periods of 2003-06. J. Appl. Meteor. Climatol., 47, 3089-3098, 2008.

Nautra, A.: Lightning storm damages in Israel, Meteorologia BeIsrael 3-4/82, 33-38, 1982 (in Hebrew).

Oke, T. R.: Boundary Layer Climates, Methuen Press, London, 302-303, 1987.

Price, C. and Federmesser, B.: Lightning-rainfall relationships in Mediterranean winter thunderstorms, Geophys. Res. Lett., 33, L07813, doi:10.1029/2005GL024794, 2006.

Price, C. and Rind, D.: A simple lightning parameterization for calculating global lightning distributions, J. Geophys. Res., 97(D9), 9919-9933, doi:10.1029/92JD00719, 1992.

Rakov, A. and Uman, M. A.: Lightning: Physics and Effects, Cambridge University Press, Cambridge, U.K., 2003, 687 pp., ISBN 0-521-58327-6, 2003.

Rodwell, M. J. and Hoskins, B.: Monsoons and the dynamic of deserts, Q. J. Roy. Meteor. Soc., 122, 1385-1404, 1996.

Romem, M., Ziv, B., and Saaroni, H.: Scenarios in the development of Mediterranean cyclones, Adv. GeoSci., 12, 59-65, 2007.

Rubin, S., Ziv, B., and Paldor, N.: Tropical Plumes over eastern North Africa as a source of rain in the Middle East, Mon. Weather. Rev., 35(12), 4135-4148, 2007.

Saaroni, H., Ziv, B., Alpert, P., and Bitan, A: Easterly wind storms over Israel, Theor. Appl. Climatol., 59, 61-77, 1998.

Saaroni, H. and Ziv, B.: Summer rain episodes in a Mediterranean climate - the case of Israel: climatological-dynamical analysis, Int. J. Climatol., 20, 191-209, 2000.

Saaroni, H., Ben-Dor, E., Bitan, A., and Potchter, O.: Spatial distribution and microscale characteristics of the urban heat island in Tel-Aviv, Israel, Landscape Urban Plann., 48, 1-18, 2000.

Saaroni, H., Halfon, N., Ziv, B., Alpert, P., and Kutiel, H.: Links between the rainfall regime in Israel and location and intensity of Cyprus lows, Int. J. Climatol., 30, 1014-1025, doi:10.1002/joc.1912, 2010a.

Saaroni, H., Ziv, B., Osetinsky, I., and Alpert, P.: Factors governing the inter-annual variation and the long-term trend of the $850-\mathrm{hPa}$ temperature over Israel, Q. J. Roy. Met. Soc., B, 136, 305-318, doi:10.1002/qj.580, 2010b.

Sharon, D. and Kutiel, H.: The distribution of rainfall intensity in Israel, its regional and seasonal variations and its climatological evaluation, Int. J. Climatol., 6, 277-291, 1986.

Shay-El, Y. and Alpert, P.: A diagnostic study of winter diabatic heating in the Mediterranean in relation to cyclones, Q. J. Roy. Meteorol. Soc., 117, 715-747, 1991. 
Yair, Y., Levin, Z., and Altaratz, O.: Lightning phenomenology in the Tel-Aviv area from 1989 to 1996, J. Geophys. Res., 103, 9015-9025, 1998.

Ziv, B.: A subtropical rainstorm associated with a tropical plume over Africa and the Middle-East, Theor. App. Clim., 69, 1/2, 91$102,2001$.
Ziv, B., Saaroni, H., and Alpert, P.: The factors governing the summer regime of the eastern Mediterranean, Int. J. Climatol., 24, 1859-1871, 2004.

Ziv, B., Saaroni, H., Yair, Y., Ganot, M., Baharad, A., and Isaschari, D.: Atmospheric factors governing winter thunderstorms in the coastal region of the Eastern Mediterranean, Theor. App. Clim., 95, 301-310, 2009. 